\title{
SPECTRAL INDICES OF VEGETATION TO CAATINGA OF THE AREA OF SEMI-ARID OF RIO GRANDE OF NORTE, BRAZIL *
}

\author{
Joel Medeiros Bezerra ${ }^{* *}$; Rochele Sheila Vasconcelos ${ }^{* * *}$; Geber Barbosa de \\ Albuquerque Moura $^{* * * *} ;$ José Espínola Sobrinho ${ }^{* * * * *}$
}

\footnotetext{
* Part of the dissertation of the first author in the Postgraduate Program in Agricultural Engineering from the Federal University of Rural Pernambuco - UFRPE, Recife-PE, Brazil.

** Masters student in Agricultural Engineering in UFRPE, DTR. Recife-PE, Brazil. Phone: 55+81 97675643.

*** Doctoral student in Agricultural Engineering in UFRPE, DTR. Recife-PE, Brazil. Phone: 55+81 98405750. ***** Adunct teacher, Agronomy Department - DEPA, UFRPE. Recife-PE, Brazil.

***** Associate teacher, Department of Environmental Sciences and Technology - DCAT, Federal University Rural do Semi-Arid - UFERSA, Mossoró-RN-Brazil.
}

\begin{abstract}
The Caatinga is an exclusively Brazilian vegetation, predominantly in the Northeast, which covers $10 \%$ of the country, being an environment understudied, especially in view of remote sensing. Thus, the aim of this study is to analyze the spatial and temporal changes in vegetation of Caatinga, in the period from 2008 to 2011, through products and techniques of remote sensing data from the Landsat 5 TM, combined with weather data. The study was conducted in the area of the proposed National Park of Furna Feia located in the municipalities of Mossoró and Baraúna in the state of Rio Grande of Norte, situated in the semiarid region of northeastern Brazil. We used three images from Landsat 5 TM satellite orbit point 63 and 216 on the following dates: 13 August 2008, 01 September 2009 and 06 August 2011. The image processing for calculating the Normalized Difference Vegetation Index values (NDVI) was performed with ERDAS Imagine 9.1 and ArcGIS 9.3. The junction of products from remote sensing with weather data allowed a coherent and reasoned, where they subsidize an understanding of physical phenomena relating to rainfall variability of the response timeline of Caatinga vegetation. There was an increase in NDVI values over the years studied, noting the direct relationship with the occurrence of rainfall.
\end{abstract}

Keywords: Remote sensing, rainfall, National Park of Furna Feia.

\section{Introduction}

The Caatinga is an exclusively Brazilian vegetation, predominantly in the Northeast, which covers $10 \%$ of the national territory. Despite being the only genuinely Brazilian vegetation, few protective actions are

Corresponding author: joel_medeiros@ oi.com.br. developed, since approximately $50 \%$ of this environment has been degraded because of human activities replacing native vegetation, especially the activities of animal husbandry, agriculture and deforestation are changing the natural landscape this ecosystem (Brasil, 
2010). Being such environmental changes rarely considered in the management of water resources (Gordon et al, 2005).

The increase in targeted areas to agricultural activities on areas of natural vegetation of Caatinga in recent decades in the Apodi plateau has resulted in increased use of surface water and groundwater for irrigation. The region has an area of Apodi $1600.40 \mathrm{~km}^{2}$ of vegetation Caatinga, and the Caatinga areas disturbed until 2002 were $692.05 \mathrm{~km}^{2}$ and between the years 2002 to 2008 was $27.03 \mathrm{~km}^{2}$ (Brasil, 2010).

Aiming to meet the demand of technological resources and evaluation techniques and spatial analysis in recent years, the advancement of space technology enabled the development of remote sensors capable of monitoring the spectral variation of vegetation that covers a particular area. Being a technique easier and less costly, in which generally uses satellite images.

The Caatinga is an environment understudied, especially in view of remote sensing analysis of vegetation. Some natural elements Caatinga as rocky substrates associated with reliefs injured with little vegetation, rangeland region of dunes, among others, have similar spectral responses to disturbed areas (Brasil, 2010), which makes a qualitative analysis of its surface. Moreover, its spatial heterogeneity generates a large spectral variability that needs to be examined very carefully.
Various techniques have been studied in order to determine quantitatively and qualitatively as would the vegetation from satellite imagery. Vegetation indices were then developed to reduce the number of parameters present in the multispectral measurements (Filho et al., 2007). These indices are generated from remotely sensed data are an important strategy for monitoring changes natural or man-made ecosystems (Holben et al., 1980; Baret \& Guyot, 1991).

The spectral behavior of the targets surface, drawn from the reflectance in the visible bands (V) and infrared (IR), provides access to information on the vegetation of a region, which enables the delineation of areas vegetated with coverage throughout the globe (Braga et al., 2000).

The Normalized Difference Vegetation Index values (NDVI) is an important parameter for monitoring vegetation and is used to build profiles, seasonal and temporal activity of vegetation, which allows interannual comparisons of these profiles (Ponzoni \& Shimabukuro, 2009).

Precipitation is one of the main driving forces for the availability of biomass in dry areas and therefore highly correlated with vegetation. By gathering this feature, the semiarid region is a sensitive indicator of climate change (Brinkmann et al., 2011). Changes in rainfall could affect directly the response of vegetation and consequently the components of the hydrological cycle (Cunha et al., 2012). 
The aim of this study is to analyze the changes in the timeline of Caatinga vegetation, during the period from 2008 to 2011, through products and techniques of remote sensing data from the Landsat 5 TM, combined with weather data.

\section{Materials and Methods}

\subsection{Study Area}

The work was conducted at the Parque Nacional da Furna Feia located in the municipalities of Mossoró and Baraúna of Norte, situated in the semiarid region northeast Brazil (Figure 1).

The National Parkof Furna Feia is a proposal to establish a Conservation Unit (UC) prepared by the federal outpost shared CECAV (National Centre for Research and Conservation of Caves, linked to the Chico Mendes Institute for Biodiversity Conservation - ICMBio) in the state of Rio Grande of Norte. Being situated in part of the legal reserve of the old farm Maisa today Settlement Project Maisa (Bento \& Cruz, 2011). (5³3'03"S, 37³0'56"W), state of Rio Grande
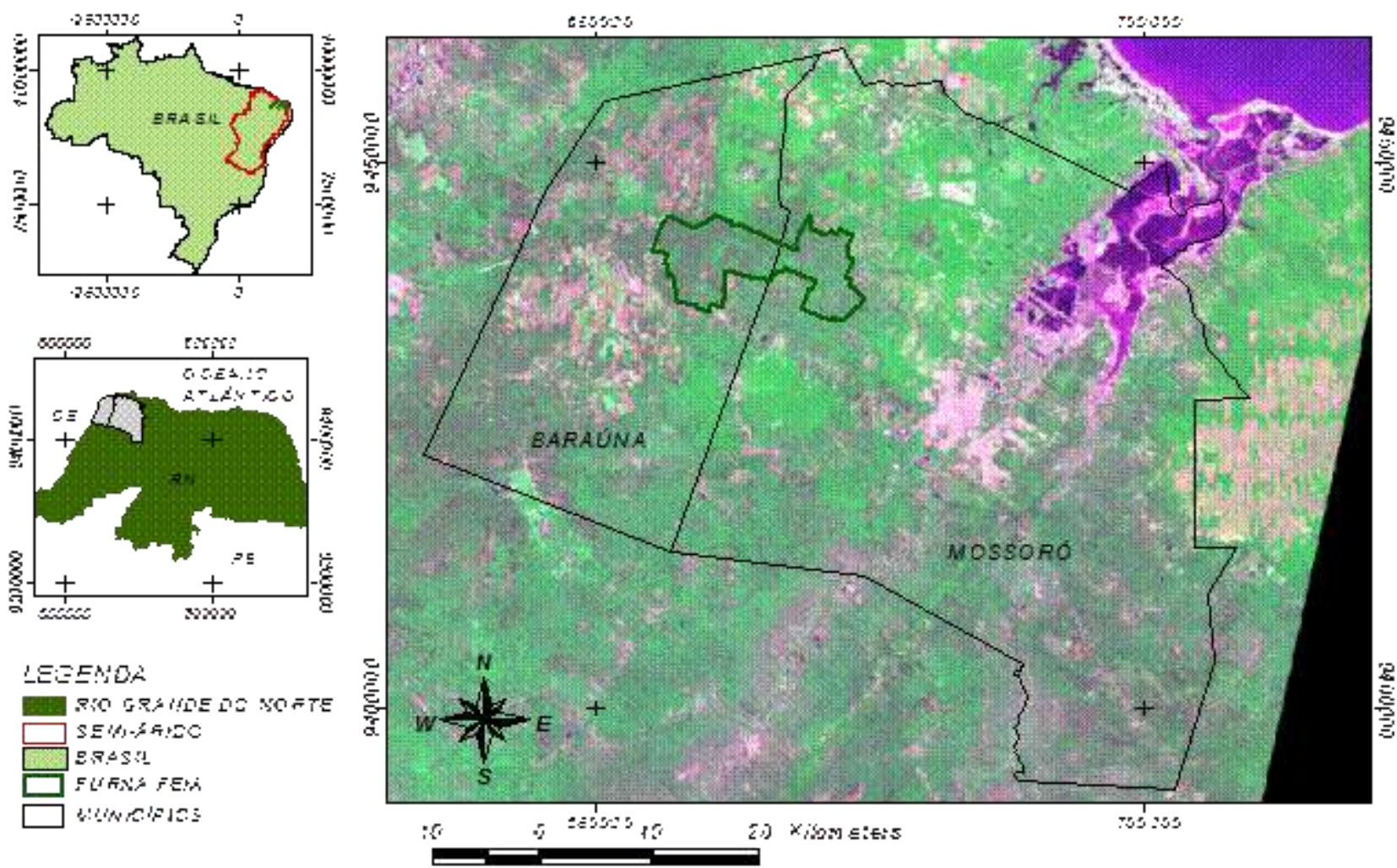

Figure 1 - Location map of the semiarid region of Brazil, Rio Grande of Norte and National Parkof Furna Feia situated in the municipalities of Mossoró and Baraúna.

The study includes an area containing native vegetation of Caatinga and limestone outcrops preserved, currently covering 10,185.7 hectares (Figure 2) and is considered a rich natural heritage, representing the largest conservation area in Caatinga areas and higher among Full Protection state, considering only terrestrial environments. It is a well-preserved 
area of xerophytic deciduous vegetation with a Brazilian fauna and flora rich and lush, with deciduous Hiperxerófila

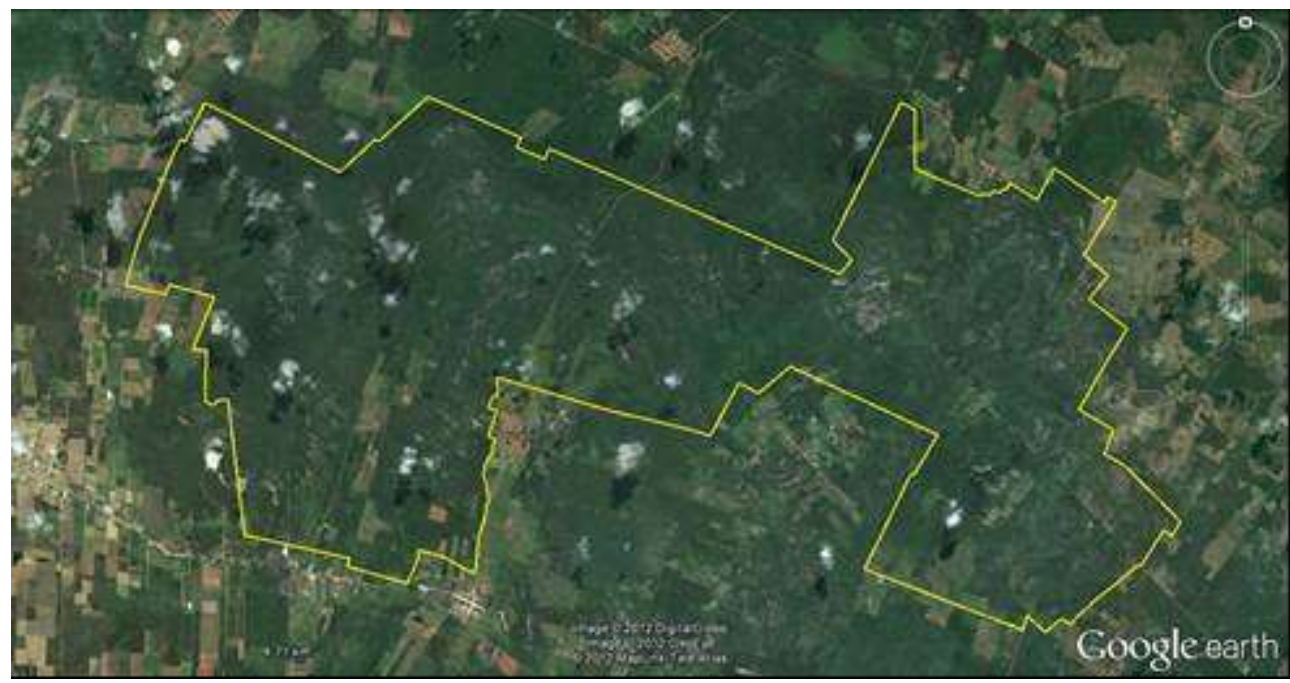

Figure 2 - Definition of theNational Park of Furna Feia. physiognomy, thus characterizing an ecosystem with species typical of semiarid Northeast (Bento \& Cruz, 2011).
According to Bento and Cruz (2011), the surveys presented, even though preliminary, odd signal a biodiversity: 105 species of plants distributed in 83 genera and 42 families, 22 species endemic to the Caatinga. It is noteworthy that several species are listed on the official lists of flora and fauna threatened with extinction training in the area is predominant vegetation type Caatinga shrubs and trees, with a high degree of soil cover. According to the Koppen climate classification of the region is the predominant type BSw'h', characterized by being very hot and semi-arid, with the rainy season was delayed to autumn, as shown in Figure 3, which covers the period from 2008 to 2011.

The climatological normals in the region, according Chagas (1997), show average annual temperature of $27.6^{\circ} \mathrm{C}, 33.5^{\circ} \mathrm{C}$ maximum and minimum of $22.8^{\circ} \mathrm{C}$, and in December the hottest month and July the coldest. The average annual precipitation is $772.7 \mathrm{~mm}$, the prevailing winds are from the northeast and southeast, with average annual speed of $3.9 \mathrm{~m} / \mathrm{s}$. The annual average atmospheric pressure is $757.1 \mathrm{mmHg}$, reaching a maximum value in July around $758.7 \mathrm{mmHg}$ and a minimum in December of $756.2 \mathrm{mmHg}$. The average evaporation measured by the evaporimeter Piché and tank class "A" is 174.7 and $231.1 \mathrm{~mm} / \mathrm{month}$, respectively. The relative humidity, cloudiness and sunshine have annual average of $68.1 \%, 4 / 10$ and 241.7 hours, respectively. 


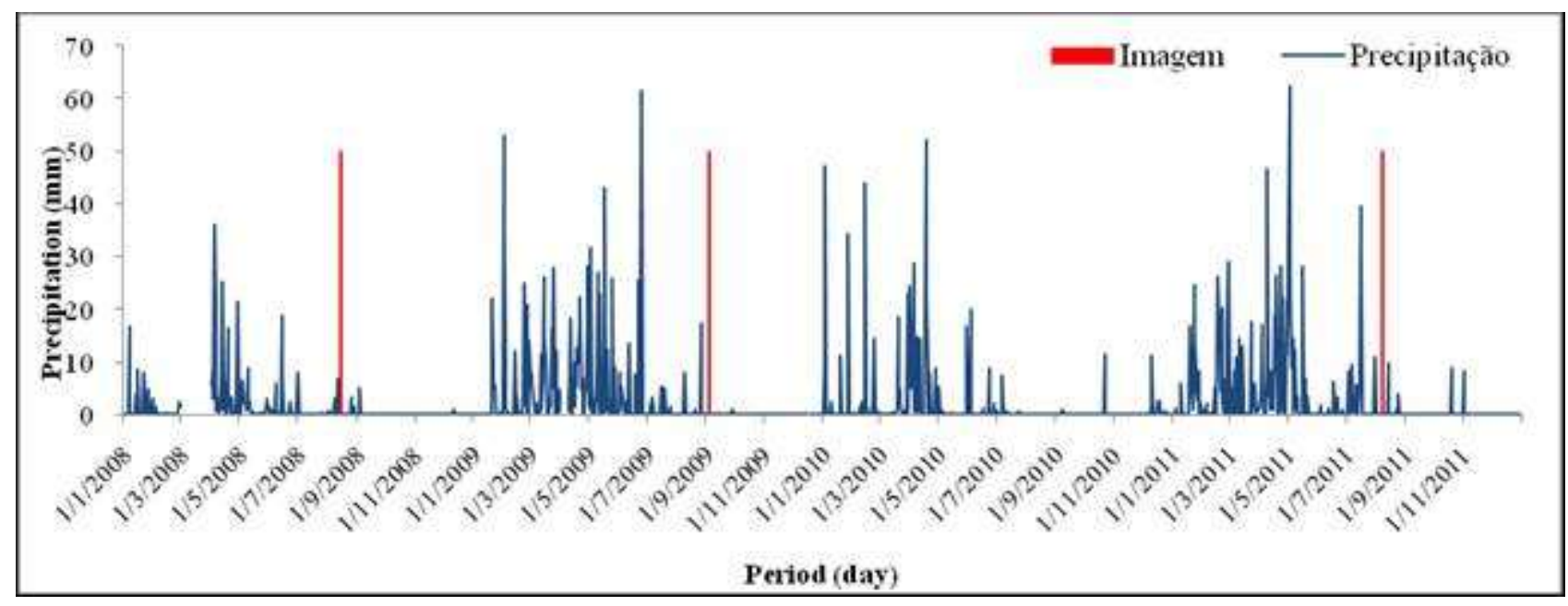

Figure 3 - Graph of precipitaion weather of station Mossoró / RN.

The soils of the study area are originated from limestone Formation Jandaíra classified as Cambisol and Udorthent (EMBRAPA, 1999), see Figure 4.



Figura 4 - Map of pedology and hydrology of the municipalities and Mossoró Baraúna.

To evaluate the behavior of Caatinga vegetation located within the conservation area of Furna Feia, it was decided to segregate the three sub-areas, enabling a space-time analysis, related to the seasonality of the period of rainfall and topography. Subareas being located as shown in (Figure 5). 


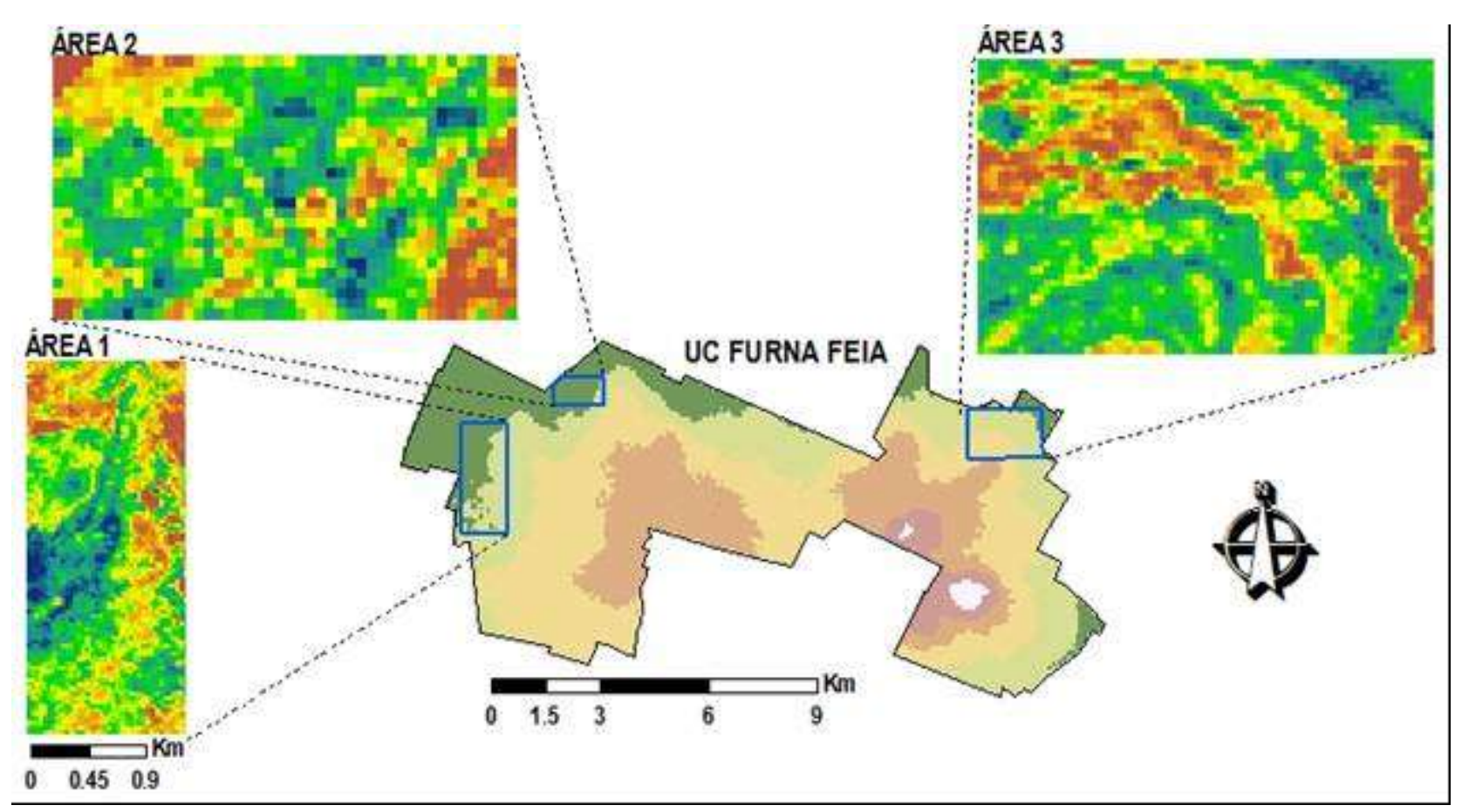

Figure 5 - Location of the three subareas of study, located within Unit Conservation of Furna Feia.

\subsection{Satellite data and meteorological}

We used three images from Landsat 5 TM, which were obtained in the image catalog of the National Institute for Space Research (INPE), the orbit / Section 216/63 that cover the study area, for the dates shown in Table 1.

The selection of images was performed considering the spatial coverage of the study area and temporal distribution that allows studying the different periods of the year as the seasonal climate, and even if there was no or minimal cloud cover.

Table 1. Images TM/Landsat-5 with date coverage of orbits and 216/63. source:

\begin{tabular}{cccc}
\hline DSA & $\mathbf{1 9 3}$ & $\mathbf{2 7 6}$ & $\mathbf{2 1 8}$ \\
\hline Image Date & $12-07-$ & $03-10-$ & $06-08-$ \\
& 2008 & 2009 & 2011 \\
Elevation Angle & 49,343 & 63,215 & 52,517 \\
Cos Z & 0,7586 & 0,8927 & 0,7935 \\
Passage time & $09: 27: 32$ & $09: 30: 36$ & $09: 29: 32$ \\
\hline
\end{tabular}

\begin{tabular}{l} 
dr $0,9675 \quad 1,0013 \quad 0,9730$ \\
\hline DSA: Sequential Day of the Year; Cos Z: Cosine of \\
zenith angle; dr: square of the ratio between the earth- \\
sun distance and their average value.
\end{tabular}

For determination of the Digital Elevation Model was used pictures of Shuttle Radar Topography Mission (SRTM), products SB-24 and SB-XC-XD-24, which provides the altitude of each pixel area.

For display and performance of mathematical operations intra and inter banda, registration, clippings, classification, it was necessary to use Geographic Information System (GIS), where the ERDAS Imagine ${ }^{\circledR}$ 9.1 of Leica Geosystems and ESRI ArcGIS ${ }^{\circledR}$ 9.3.

First sued the calibrations of atmospheric images, radiometric calibration is performed by converting the digital number (ND) or intensity of each pixel of the image in monochromatic spectral radiance $\mathrm{L}_{\lambda \mathrm{i}}$ and for 
the reflective bands of Landsat 5 TM (channels 1, 2 3, 4, 5 and 7) was used the following relationship Markhame proposed by Baker (1987):

$$
\mathrm{L} \lambda \mathrm{i}=\mathrm{a}_{i}+\left(\frac{b_{i}-\mathrm{a}_{i}}{255}\right) N i(1)
$$

Where $\mathrm{a}$ and $\mathrm{b}$ are the minimum and maximum spectral radiance $\left(\mathrm{W} \mathrm{m} \mathrm{m}^{-2} \mathrm{sr}^{-1} \mu \mathrm{m}^{-1}\right)$, determined by Chander \& Markham (2003), valid for images of recent years. ND is the number of digital pixel (integer from 0 to 255 , in the case of Landsat) and $i$ corresponding to bands 1, 2, 3, 4, 5, 6, 7, Landsat TM 5.

With thematic maps of spectral radiance of each band, information about the cosine of the Sun zenith angle $(\cos Z)$ and the directional spectral flux at the top of the atmosphere $\left(\mathrm{K}_{\lambda \mathrm{i}}\right)$ of each band was estimated planetary reflectance each band using the following equation Bastiaanssen (1995):

$\rho_{\lambda \mathrm{i}}=\frac{\pi L_{\lambda, \tilde{\mathrm{i}}}}{K_{\mathrm{\lambda}_{\mathrm{i}} \cdot \cos Z \cdot d}}(2)$

In what is the planetary reflectance of band $\mathrm{i}$ is the solar spectral directional flow at the top of the atmosphere, $\mathrm{Z}$ is the zenith angle of the Sun (obtained directly in own catalog of images from INPE), and dr is the square of the ratio between the average distance Earth-Sun and Earth-Sun distance on any given day of the year (DSA), which according to Iqbal (1983), is given by:

$$
d_{r}=1+0,033 \cos (D S A .2 \pi / 365)(3)
$$

Where DSA represents sequential day of the year and the argument of the cosine function in radians. The average annual value is equal to 1.00 . The $\pi(\mathrm{sr})$ is a constant resulting from hemispheric integration of spectral radiance.

The Vegetation Index (NDVI) is the ratio between the difference of the reflectivities of near-Infrared $\left(\rho_{v i}\right)$ and red $\left(\rho_{v}\right)$, the sum of them.

$$
N D V I=\frac{\rho_{i v}-\rho_{v}}{\rho_{i v}+\rho_{v}}(4)
$$

They correspond, respectively, the bands 4 and 3 of the 5 Landsat TM. The NDVI serves as a sensitive indicator of the quantity and condition of vegetation, their values range from 1 to +1 . For surfaces with some vegetation NDVI from 0 and 1; now to water and clouds NDVI is generally less than zero.

The meteorological data used were obtained from the meteorological station of UFERSA - Federal Rural University of Semiarid $\left(5^{\circ} 11^{\prime} 00^{\prime \prime} \mathrm{S}, 37^{\circ} 20^{\prime} 00^{\prime \prime} \mathrm{W}\right.$ and altitude of $18 \mathrm{~m}$ ) and is $24.50 \mathrm{~km}$ of the area in question, located in the municipality Mossoró, near the study area. Which provided the daily rainfall data for the period under study.

\subsection{Statistical Analysis}

The data were analyzed using the program Statistica7, getting the main parameters of classical statistics (mean, minimum, maximum, variance, coefficient of variation, kurtosis, asymmetry coefficient, frequency distribution and obtain the maximum deviation of the distribution normal or log normal through the test error probability Kolmogorov-Smirnov with $5 \%$ level of probability). 
To detect significant variability in spatial and temporal vegetation index (NDVI), we applied the Tukey test at 5\%, to each image, using the three sub-areas defined in Figure 5.

\section{Results and Discussion}

Table 2 presents the main parameters of the statistical analysis for the study in three scenes, grouped into sub-areas. According to the coefficient of variation data variability NDVI was classified, according to Warrick \& Nielsen (1980), considering three levels of variability, low variability when $\mathrm{CV}<12 \%$, average variability for the range of $12 \%$ to $60 \%$, and high variability for $\mathrm{CV}>60 \%$.

The sub-area 1 presented medium CV for the periods 2008 and 2009, while for the year 2011 CV low. In sub-area 2 was observed $\mathrm{CV}$ low in all periods under study. In sub-area 3 showed medium CV for the periods 2008 and 2009, while for the year 2011 CV low, behavior similar to sub-area 1 .This fact can be explained by the influence of seasonal rainfall events, as shown in Figure 3, it was observed that the acquisition of the satellite image was taken during the period of declining rainfall regime, with water availability in the soil and vegetation cover present, and the effects of water stress minimized at that moment, due to part of the water is stored in the topsoil.

It appears that for the scene of 2011 all three sub-areas presented low CV, as this period was characterized by the occurrence of an event of precipitation record of $39.37 \mathrm{~mm}$ on the date of $16 / 07 / 2011$ and is very near the obtaining image satellite 06/08/2011, thus minizando the heterogeneity of vegetation cover, besides reducing the temperature of the soil surface for moisture retention thereof.It was also observed that the increasing trend mean values of NDVI of the 3 areas, which refers to the process of resilience on the part of native vegetation anthropized, combined susceptibility of species and biomass production favored by precipitation events.

As Figure 3 shows the occurrence of regime rainfall concentrated in a short time (torrential rains), followed by a prolonged period of decline, marking the beginning of the dry season. The occurrence of such events provided the variability spatio-temporal response of vegetation within the study area.

The Kolmogorov-Smirnov test has shown that all attributes in the study had normal frequency distribution, a fact that is evidenced by the values of skewness and kurtosis, which present approach 0 and 3, respectively.

We also observe the presence of seasonal behavior in the scenes in the study, due to the extreme values of maximum and minimum, and average values. Despite the sub-areas are so near to form planialtimetric (Figure 5), has the effect of spatial variability, corroborated by the gradient of altimetry relief, as shown in Figure 6, where the subarea 3 showed the highest NDVI during the study period, being next to the same elevations in relief (hills region), restricting the use of certain anthropic activities. 
Table 2 - Parameters of the statistical sub-areas for the periods under study

\begin{tabular}{|c|c|c|c|c|c|c|c|c|c|c|c|}
\hline Sub-area & Period & $\mathrm{N}$ (pixels) & Min & Max & Mean & Med & SD & $\mathrm{CV}$ & skewness & kurtosis & D \\
\hline \multirow{3}{*}{ Área 1} & 2008 & \multirow{3}{*}{4158} & 0.184 & 0.629 & 0.441 & 0.445 & 0.074 & 16.79 & -0.339 & -0.013 & $0.042 \mathrm{n}$ \\
\hline & 2009 & & 0.217 & 0.725 & 0.542 & 0.552 & 0.080 & 14.77 & -0.812 & 0.617 & $0.067 \mathrm{n}$ \\
\hline & 2011 & & 0.219 & 0.717 & 0.609 & 0.629 & 0.072 & 11.77 & -2.191 & 5.969 & $0.155 \mathrm{n}$ \\
\hline \multirow{3}{*}{ Área 2} & 2008 & \multirow{3}{*}{1196} & 0.312 & 0.579 & 0.473 & 0.478 & 0.048 & 10.13 & -0.717 & 0.471 & $0.076 \mathrm{n}$ \\
\hline & 2009 & & 0.319 & 0.696 & 0.585 & 0.599 & 0.065 & 11.07 & -1.258 & 2.432 & $0.085 \mathrm{n}$ \\
\hline & 2011 & & 0.319 & 0.687 & 0.613 & 0.620 & 0.045 & 7.27 & -2.596 & 14.203 & $0.086 \mathrm{n}$ \\
\hline \multirow{3}{*}{ Área 3} & 2008 & \multirow{3}{*}{2992} & 0.243 & 0.699 & 0.515 & 0.534 & 0.091 & 17.56 & -0.545 & -0.58 & $0.092 \mathrm{n}$ \\
\hline & 2009 & & 0.216 & 0.723 & 0.544 & 0.554 & 0.087 & 15.95 & -0.508 & -0.168 & $0.058 \mathrm{n}$ \\
\hline & 2011 & & 0.319 & 0.703 & 0.567 & 0.574 & 0.066 & 11.70 & -0.68 & 0.415 & $0.068 \mathrm{n}$ \\
\hline
\end{tabular}

N: number of measurements; Mín.: value mínimo; Máx.: value máximo; Med.: Valuemedian; SD: Standard Deviation; $\mathrm{CV}$ : Coefficient of Variation (\%);D: maximum deviation relative to normal frequency distribution by means of the statistical test of Kolmogorov-Smirnov test with probability of error of 5\%; n: normal frequency distribution; Ln: frequency distribution lognormal.

Corroborating Sampaio (2003), where rainfall influence the distribution of species and biomass production, as well as the geographic location, the configuration of the terrain and the climate and soil conditions (fertility, organic matter content, rainfall regime, air temperature and soil depth).

For greater representation of NDVI scenes of 2008, 2009 and 2011 were reclassified in eight classes, where the NDVI ranged from 0.1 to 0.8 , according to the figure 6 , where the evolution is presented in the study area.

According to Rodrigues et al. (2009), the NDVI when evaluated on a seasonal and long term, can be an important indicator of desertification and mitigating the Caatinga biomass. 


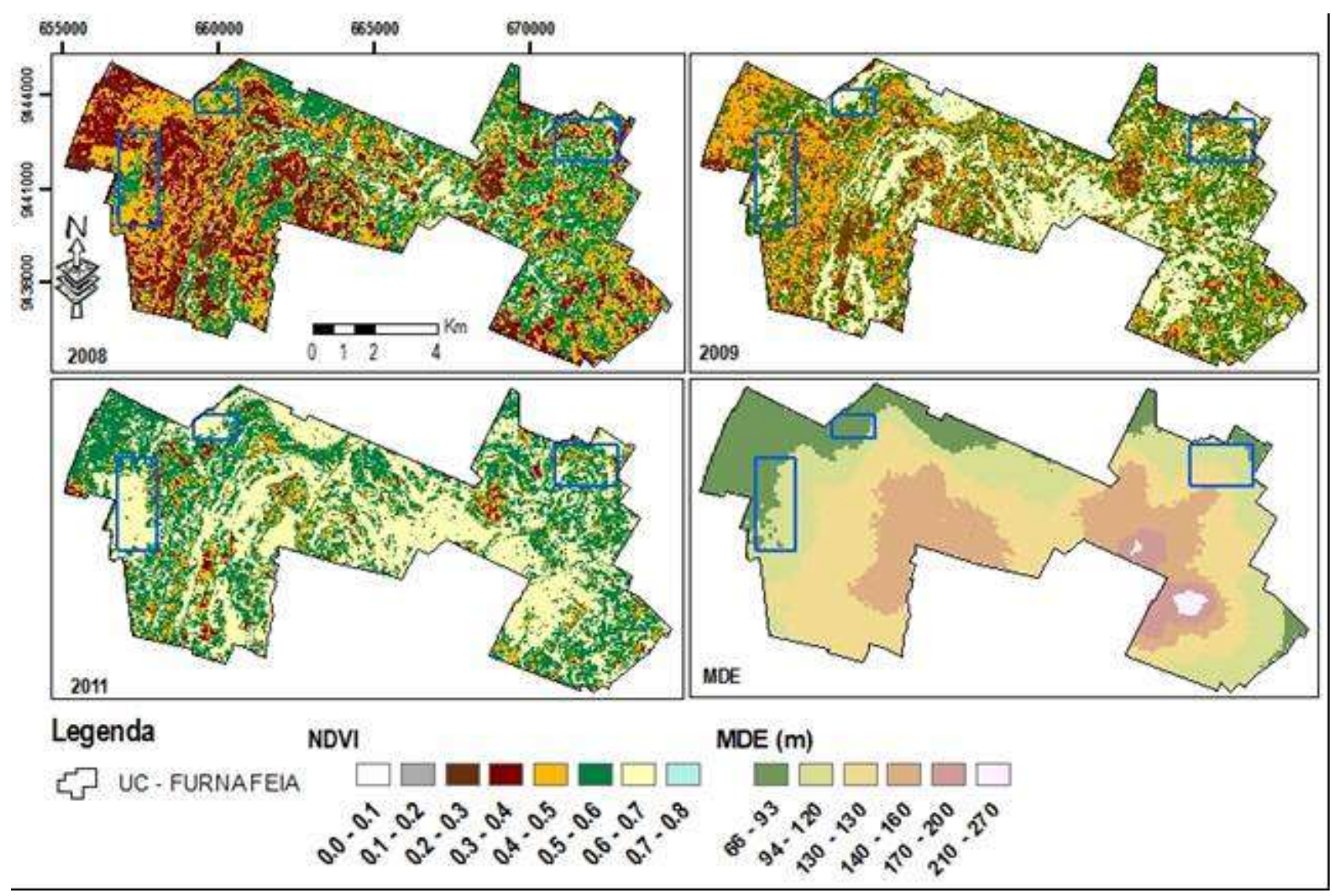

Figure 6 - Distribution temporal space of NDVI values for the area of UC Furna Feia.

The smaller NDVI values obtained correspond to exposed soil and rock outcroppings, the intermediate values are represented by Caatinga vegetation more sparse undergrowth and the highest values and the vegetation of Caatinga more condensed and possibly tree, located in areas with higher altitude and slope (Figure 6), both north and south, leaving more vegetated (NVDI> 0.5) occurring even gain in intensity and area of vegetation coverage (presence of higher values between 0.5 and 0.7$)$.

Analyzing the area of the Conservation Unit of Furna Ugly in a general way observed that the scene of 2011 had a higher percentage of high NDVI values (0.6 to 0.8 ) in response to cumulative rainfall of $964.43 \mathrm{~mm} \mathrm{year}^{-}$
1 annual, while scenes of 2008 and 2009 had accumulated rainfall of $333.50 \mathrm{~mm} \mathrm{yr}^{-1}$ and $988.30 \mathrm{~mm} \mathrm{yr}^{-1}$, respectively.

The altitude is a factor that controls the amount of local rainfall, changing the overall landscape of vegetation, it was observed that in the years 2009 and 2011 there were higher values of rainfall for the year 2008, however it is clear that areas at high altitudes had the highest NDVI values, which can be observed through the MDE (Figure 6).

The evolution temporal space presented in Figure 6, it can be said that there was preservation of native vegetation of Caatinga, and occur NDVI increased over the years due to pluviometric regime, associated to edafoclimates local conditions. 
Figure 7 shows graphs of frequency three sub-areas, the course of the study period. distribution relative to NDVI behavior in the
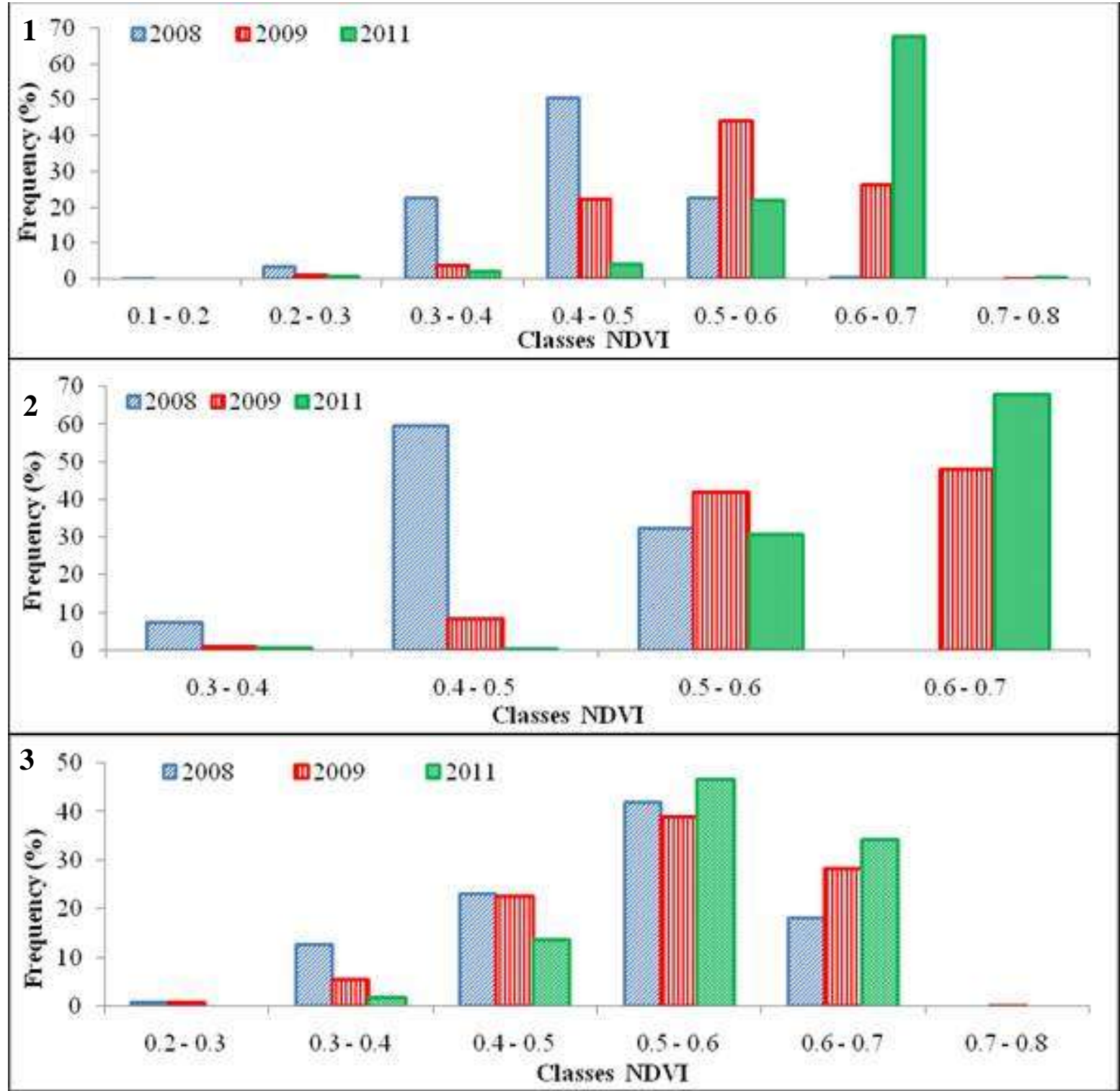

Figure 7 - Graph of frequency distribution relative to NDVI 3 subareas $(1,2$ and 3$)$ during the study period.

According to the chart above was no difference of NDVI in the three years studied. In subarea (1) the highest rates of NDVI occurred in the years 2009 and 2011 with higher frequencies in the range above 0.5 to 0.8. In subarea (2) was observed higher NDVI values in the years 2009 and 2011, where the year 2011 stood out with greater frequency in the class of 0.6 to 0.7.In subarea (3) NDVI remained fairly constant in all years, with the highest frequency observed in the class from 0.5 to 0.6 . Therefore, the sub-area 3 is presented as the area least altered by anthropogenic activities and is stable compared with other sub-areas of study.

The vegetation of Caatinga responds quickly to seasonal occurrence of droughts and periodic, defense mechanism by activating the physiological and morphological, where the vegetation loses the shoot (the only part 
remaining woody vegetation by checking the color gray to white), thus reducing the sweating process, however soon after the occurrence of the first event of rain the leaves sprout again, reestablishing the green color during rainy (Silva, Lima \& Almeida, 2011).

Gurgel et al., (2003) studied variability of NDVI in Brazil, confirmed a high correlation between NDVI and rainfall variable. Although the Caatinga be considered as a biome high fragility, its high power resilience is confirmed by the immediate formation of biomass in response to the rain events. This behavior of the semi-arid vegetation in response to rainfall events was also observed by Barbosa et al., (2006), which showed the resilience of the vegetation during drought periods.

According to Table 3, there is a statistical analysis by Tukey test at 5\% probability, where there was a significant difference in the three areas studied, observing an increasing NDVI over the years.

Table 3 - Average of NDVI scenes for three areas in the years 2008, 2009 and 2011

\begin{tabular}{cccc}
\hline years & Area 1 & Area 2 & Area 3 \\
\hline 2008 & $0,441 \mathrm{a}$ & $0,473 \mathrm{a}$ & $0,515 \mathrm{a}$ \\
2009 & $0,542 \mathrm{~b}$ & $0,585 \mathrm{~b}$ & $0,544 \mathrm{~b}$ \\
2011 & $0,609 \mathrm{c}$ & $0,613 \mathrm{c}$ & $0,567 \mathrm{c}$ \\
\hline Médias & 0,531 & 0,557 & 0,542 \\
\hline
\end{tabular}

Médias seguidas de letras iguais na vertical não diferem entre si pelo teste de Tukey a 5\%.

The largest contribution to the increase of NDVI over the years was the pluviometric regime, a fact related to thematic maps of Figure 6, where we can observe the spatial variability of NDVI within the conservation unit Furna Feia, beyond graphics of relative frequency of NDVI classes of Figure 7 , in both cases it is observed that in
2011 there was a peak pluvial precipitation closer to months before analysis.

With the aid of Figure 8, is related to the pluvial precipitation regime behavior of NDVI, restricting itself to detailing the daily precipitation over the past 3 months prior to obtaining the satellite image Landsat $5 \mathrm{TM}$.








Figure 8 - Distribution of daily rainfall for the period of 3 months prior to obtaining satellite images.

Figure 8 consolidates the hypothesis of variability spatio temporal, relating directly to rainfall events, where the scene of 2011 acted in response to the event of $16 / 07 / 2011$, as the scene of 2008 responded to the rainfall event on $12 / 08 / 2008$, with all scenes include the period of decreased pluvial precipitation.

\section{Conclusion}

The use of remote sensing techniques for processing satellite images, specifically the NDVI, proved quite efficient to analyze the changes in the temporal space of Caatinga vegetation cover and land use patterns.

The junction of products from remote sensing with meteorological data allows a coherent approach and reasoned, where they subsidize an understanding of physical phenomena relating to pluvial precipitation variability of the response temporal space of Caatinga vegetation.

There was an increase in NDVI values over the years studied, noting the direct relationship with the occurrence of pluvial precipitation, combined with conservation of vegetation, beyond the process of resilience of the vegetation anthropized.

\section{Acknowledgements}

The authors thank the National Council for Scientific and Technological Development $(\mathrm{CNPq})$ and the Coordination of Improvement of Personnel of Superior Level (CAPES) for the financial support. Besides the institution of the Federal Rural University of the Semi-Arid (UFERSA) for disposal of meteorological data and the Chico Mendes Institute (ICMBio) to 
have technical information about the UC Furna Feia.

\section{References}

Allen, R.G. et al. Surface Energy Balance Algorithm for Land (SEBAL) - Advanced training and user's Manual. Idaho, 98, 2002.

Barbosa, H.A.; Hueti, A.R.; Baethgen, W.E. 2006. A 20 - year study of NDVI variability over the Northeast Region of Brazil. Journal of Arid Environments, London, 67, 288-307.

Baret, G.; Guyot, G. 1991. Potentials and limits of vegetation indices for LAI and APAR assessment. Remote Sensing of Environment, (35), 161-173.

Bastiaanssen, W. G. M. 1995. Regionalization of surface flux densities and moisture indicators in composite terrain. Ph.D. Thesis, Wageningen Agricultural University, Wageningen, Netherlands, 237.

Bento, D. M.; Cruz, J. B. Proposta de criação de unidade de conservação federal parque nacional da Furna Feia Municípios de Baraúna e Mossoró no Estado do Rio Grande do Norte, 2011. Disponível em: http://www.icmbio.gov.br/portal/images/sto ries/o-quefazemos/parnadafurnafeirasite.pdf Acesso em: Maio de 2012.

Braga, C. C.; Sansigolo, C. A; Rao, T. V. R. Padrões de variabilidade espaciais e temporais de NDVI na região nordeste do Brasil utilizando análise fatorial. Anais....Congresso Brasileiro de
Meteorologia (CBMET), 2000 Edição XI. Rio de Janeiro, RJ, 2000.

Brasil, Ibama; MMA. Monitoramento do desmatamento nos biomas brasileiros por satélite - Monitoramento do Bioma caatinga 2002 a 2008. Centro de Sensoriamento Remoto - CSR/IBAMA, 2010. Disponível em: $<$ http://siscom.ibama.gov.br/monitorabioma s/caatinga/relatrio_tcnico_caatinga_72.pdf. Acesso em: Maio de 2012.

Brinkmann, K.; Dickhoefer, U.; Schlecht, E.; Buerkert, A. 2011. Quantification of aboveground rangeland productivity and anthropogenic degradation on the Arabian Peninsula using Landsat imagery and field inventory data. Remote Sensing of Environment, 115, 465-474.

Chagas, F.C. Normais Climatológicas para Mossoró, RN (1970-1996). ESAM, 1997, (Monografia de graduação em Engenharia Agronômica) 40.

Chander, G.; Markham, B. 2003. Revised Landsat-5 TM Radiometric Calibration Procedures ans Postcalibration Dynamic Ranges. IEEE Transactions on Geoscience and Remote Sensing. 41(11).

Cunha, J. E. B. L.; Rufino, I. A. A.; Silva, B. B.; Chaves, I. B. 2012. Dinâmica da cobertura vegetal para a Bacia de São João do Rio do Peixe, PB, utilizando-se sensoriamento remoto. Revista Brasileira de Engenharia Agrícola e Ambiental, 16(5). Campina Grande. 
Embrapa Solos. Sistema brasileiro de classificação de solos. Rio de Janeiro, 1999. 412.

Filho, J. F. C.; Francisco, P. R. M.; Andrade, M. V.; Silva, L.; Dantas, R. L. D. Estimativa do índice de vegetação da diferença normalizada (NDVI) na microrregião de Sousa-PB utilizando imagens do CBERS-2. Anais... XV Congresso Brasileiro de Agrometeorológica, Aracaju-SE, 2007.

Gordon, L.J.; Steffen, W.; Jönsson, B.F.; Folke, C.; Falkenmark, M.; Johannesen, 2005. A. Human modification of global water vapor flows from the land surface. Proceedings of the National Academy of Sciences, 102 (21), 7612-7617.

Gurgel, H.C.; Ferreira, N.J.; Luiz, A.J.B. 2003. Estudo da variabilidade do NDVI sobre o Brasil utilizando-se a análise de agrupamento. Revista Brasileira de Engenharia Agrícola e Ambiental, Campina Grande, 7(1), 85-90.

Holben, B.N.; Tucker, C.J.; Cheng-jeng, F. 1980. Spectral assessment of soyabeanleaf area and leaf biomass. Photogrammetric Engineering and Remote Sensing, 46(5), 651-656.
Markham, B. L.; Barker, L. L. 1987. Thematic mapper bandpass solar exoatmospherical irradiances, Int. Journal of Remote Sensing, 8(3), 517-523.

Ponzoni, F. J.; Shimabukuro, Y, E. Sensoriamento remoto no estudo da vegetação. São José dos Campos-SP. Ed: Parêntese, 2009.

Rodrigues, J. O.; Andrade, E. M.; Teixeira, A. S.; Silva, B. B. 2009. Sazonalidade de variáveis biofísicas em regiões semiáridas pelo emprego do sensoriamento remoto. Revista Engenharia Agrícola, Jaboticabal, 29(3), 452-465, jul./set.

Sampaio, E.V.S.B. 2003. Caracterização da caatinga e fatores ambientais que afetam a ecologia das plantas lenhosas. In: V.C. Sales (ed.). Ecossistemas brasileiros: manejo e conservação. Fortaleza, Expressão Gráfica e Editora.129-142.

Silva, K. S. T.; Lima, A.; Almeida, A. M. Estudo da sazonalidade da caatinga com dados de sensor MODIS. Anais...XV Simpósio Brasileiro de Sensoriamento Remoto- SBSR, Curitiba, PR, Brasil, 30 de abril á 05 de maio de 2011, INPE, 1881.

Warrick, A.W.; Nielsen, D.R. (1980) Spatial variability of soil physical properties in the field. In: Hillel, D. Applications of soil physics. New York: Academic Press. 